\title{
ethic@ \\ INTERPRETING THE CLAIM OF LEGITIMATE AUTHORITY: AN \\ ANALYSIS OF JOSEPH RAZ'S OBJECTION AGAINST \\ INCORPORATING MORAL NORMS INTO LAW
}

\author{
RAMIRO ÁVILA PERES ${ }^{1}$
}

(UFRGS/Brasil)

\begin{abstract}
From a critical review of the literature, we analyze the incompatibility between the possibility of incorporating moral principles to the law and its authoritative nature, as argued by exclusive positivists, such as J. Raz. After presenting his argument in second section, we argue in the third section that it is incompatible with commonly accepted (even by Raz) premises of the theory of legal interpretation, or else it would lead to contradiction - unless one presupposes, within the premises, a strong version of the sources thesis (which is what Raz intends to prove). In conclusion, we return to the arguments presented, concluding with a possible difficulty for the adoption of exclusive positivism by people inside a legal practice.
\end{abstract}

KEYWORDS: Law; Morality; Authority; Interpretation; Incorporation.

\section{Introduction}

In The Model of Rules, Ronald Dworkin criticizes the sources thesis of legal positivism, arguing that law would not be exhausted by sets of rules defined by factual tests in the rule of recognition -as set out in Hart's The Concept of Law. Besides these rules, the legal system would present another possibility of standards - so-called principles; their identity and content would be determined not by a second-order rule, but by moral interpretation and deliberation (DWORKIN, 1967). To this objection, Hart replied that his theory does not imply the identification of law consists only of historical facts; in reality, in some systems, the ultimate criterion of validity could incorporate (the incorporation thesis) principles of justice and moral values:

He [Dworkin] treats my doctrine of the rule of recognition as requiring the criteria which it provides for the identification of law must consist of only historical facts and an example of 'plain-fact positivism'. But I do not know what to say about Dworkin, but I do not know what to say about Dworkin. in this book (p. 72) and in my earlier article on 'Positivism and the Separation of Law and Morals' in some systems of law, as in the United States, the ultimate criteria of legal validity might explicitly incorporate besides pedigree, principles of justice or substantive moral values, and these may form the content of legal constitutional restraints (HART, 1994, 247).

According to this line of answer, the argument from principles would be a mistake, inasmuch as it would not apply to Hart. Some of the most prominent positivist writers have adopted another replica 
style to Dworkin's argument: in spite of what legal references to moral concepts may suggest, law does not 'incorporate' them. In fact, according to Joseph Raz, when a legal rule refers to such a concept, it creates a gap in the system, to be supplemented discretionarily by an authority.

Let us assume, for example, that by law contracts are valid only if not immoral. Any particular contract may be judged to be prima facie valid if it conforms to the 'valueneutral' conditions for the validity of the contract laid down by law. The proposition 'It is legally conclusive that this contract is valid' is neither true nor false until a court authoritatively. This is a consequence of the fact that the courts have discretion when required to apply moral considerations (RAZ, 1979, 75).

Therefore, there are three competing conceptions on this subject: Dworkin's interpretivism, Hart's inclusive positivism (which accepts the incorporation thesis), and Raz's exclusive positivism. According to the 'exclusive positivists', the impossibility of incorporating moral concepts would not be a characteristic of only a few legal systems, but a 'necessary property' of law, deriving from its own authoritative nature. Therefore, Dworkin's and Hart's theories would be inconsistent with the nature of law:

Dworkin's theory, one must conclude, is inconsistent with the authoritative nature of law. That is, it does not allow for the fact that the law necessarily claims authority and that it must be capable of possessing legitimate authority. To do so it must occupy, the all authority does, a mediating role between the precepts of morality and their application by people in their behavior. It is this mediating role of authority which is denied to the law by Dworkin's conception of it (RAZ, 1996, 225-226).

In spite of the clarity of the argument and its call for a conceptual and intuitive connection between authority and law, it seems that most people are not (or at least do not consider themselves to be) 'exclusive positivists.' If they are right, there must be something wrong with Raz's theory.

Next, we explain Raz's anti-incorporation argument and analyze some of the objections presented to it. Then, we will present a new objection, using premises derived from Raz's own theory of interpretation. In conclusion, we list a possible reply to this objection -which, however, already presupposes the sources thesis (which one wants to prove).

\section{Raz's argument}

\section{i. Every legal system claims legitimate authority.}

This is the claim thesis; Raz considers it to be one of the fundamental properties of legal systems, which distinguishes them from other 'closed normative systems' (RAZ, 2002, 163). It stems from the very nature of authority (RAZ, 1986, 26-27), distinguishing it from mere coercion: either the legal system explicitly 'claims' legitimate authority, or it is treated as if it had it (RAZ, 1995, 215). This 'claim' could be verified by the following elements: 
(1) the enforcement of law as exclusionary; (2) the use in the law of such terms as 'right' and 'duty'; (3) the official designation of legal institutions as 'authorities'; (4) the claims of officials that 'owe' allegiance and 'ought to obey the law'; and (5) the beliefs of officials that have legitimate authority (HIMMA, 2001, 283).

It may seem strange to attribute propositional or intentional attitudes to a legal system (not to people); but the meaning of this assignment is quite simple: legal authorities make such a claim on behalf of the political community. "Law makes claims only insofar as the law-applying officials make those same claims at the very same time and place." (GARDNER, 2012, 131) We can make this premise more acceptable by arguing that there is a presupposition or claim of legitimate authority that is attributable to an institution or set of persons; this 'weakened' premise would still retain the power of Raz's argument ${ }^{2}$.

Such a claim implies that his theory of authority is not axiologically empty (value-free). Hence, even if a person or institution is 'morally objectionable,' it is only an authority if it is treated by several people as morally defensible - otherwise it could not be treated as authoritatively binding; the claim in question (as well as the directives of authority) must be morally intelligible ${ }^{3}$.

ii. If the law claims legitimate authority, every legal rule is authoritative;

Although no objection to this thesis has been found, it may appear to be a non sequitur if exposed without prior explanation. In fact, it stems from the idea that the legal system can be equated with the corresponding set of norms - i.e., that it is a 'closed normative system,' as advocated by Raz $(2002,160$ ff.). But this conception of law as a closed system is precisely the more general thesis that Dworkin $(2011,401)$ rejects - what he calls the 'two systems view.' Although this issue escapes our current scope, we will return to it at the end of the article, analyzing possible exclusivist replies.

iii. To be authoritative, a norm should be able to: a. guide the agent's behavior, and $b$. be identified without the subject having to deliberate over the reasons that would justify the action determined by the norm;

This stems from the preemption thesis: "The fact that an authority requires fulfillment and an action is a reason for its realization, which should not be added to the other relevant reasons when thinking about what to do, but should replace some of them." (RAZ, 1994, 214) Authoritative directives are, in Raz's vocabulary, 'protected reasons': they are at the same time reasons for carrying out an action (reasons of first order) and reasons to exclude deliberation on other reasons (excluding, second order reasons); therefore, they can replace the original reasons that the subject would have to act. This is what makes authority authoritative.

$i v$. To be identifiable without needing to take into account the considerations that would make it justified, a standard must be founded on an attitude, belief or intention (mental states or dispositions) of someone claiming legitimate authority;

This premise seems to follow what Raz supposes to be a necessary relation between interpretation and authority: "Making law is an intentional activity. One does not make law except 
through acts committed in the knowledge that they will make law. And one cannot make law intentionally if one is totally in the dark as to which law one is making.' (RAZ, 2009, 120)

Interestingly enough, this idea seems to be refuted by one of Raz's top supporters, John Gardner, for whom there can be creation of law without a particular agent creating it (as in consuetudinary law), nor someone's intention to create law - i.e., there is unintentional creation of law (that is what judicial decisions sometimes do when establishing a doctrine or precedent). These cases are not properly exercises of authority, although we may treat them as authoritative 'in a derivative sense' (GARDNER, 2012, 87). However, if (ii) or (iv) are false (i.e., if there are legal norms that are not authoritative directives, or if there are authoritative directives that are not a 'function' of an authority's intentional attitudes), the conclusion below - the refutation of the incorporation thesis, in the sentence (vi) - does not follow. It follows only the conclusion that, for those legal norms that are effectively authoritative directives (i.e., a subgroup of the set of legal norms), we can apply (vi).

v. Norms that require the subject to interpret moral concepts to fulfill them demand that one deliberates on the reasons that would justify the prescribed behavior;

vi. Therefore, by (iii) and (v), norms that require the subject to interpret moral concepts to fulfill them are not authoritative directives. Therefore, legal norms do not require the subject to interpret moral concepts to fulfill them.

\section{The Objection: Interpretation and Authority}

We can proceed with some premises derived from Raz's theory of authority and interpretation, arriving at a contradiction:

vii. $\quad$ To be able to guide behavior / be applied, a norm must be understood;

This condition seems to derive trivially from the normative character of law: if a norm is a kind of reason to act, its relationship to the agent's behavior is not a merely of 'cause and effect', but something similar to what Mark Greenberg (2004) calls rational relation.

viii. For a norm to be understood, one must interpret the attitude on which it is based;

Considering that the exercise of authority is a volitional act, Raz considers it necessary that any interpretation that seeks to preserve the meaning of an authoritative directive should take into account the intention of its issuer. It is the Authoritative Intention thesis: 'to the extent that the law derives from deliberative law-making, its interpretation should reflect the intentions of its law-makers.' (RAZ, 2009, 275)

ix. Authoritative directives should be based (among other factors) on the firstorder reasons applicable to the subjects. 
This dependence thesis distinguishes the exercise of authority from other forms of control such as simple coercion. Along with the preemption thesis, it forms the service conception of authority (RAZ, 1995, 214).

$\mathrm{x} . \quad$ An authority is justified when a subject is more likely to attend to the her own reasons by accepting authority's directives and trying to follow them than by pursuing her own reasons directly; therefore, to be legitimate, an authority should take into account the considerations which would make the rule justified.

The normal justification thesis, although logically independent of the two main theses of the service conception (dependence and preemption), is explained by them. If what distinguishes authority is the 'service' it provides, it can be justified when it is more rational for a subject to 'outsource' deliberation than to perform it by herself.

xi. In order to interpret the attitude in question, it is necessary to take into account, at least in some cases, what would be the case if the norm that it grounds were legitimatei.e., among the possible interpretations, one selects those compatible with the statement that the authority is legitimate.

This is the most debatable premise we introduce in this argument; it is not found Raz's works. Although a separate investigation is required to support it, it is consistent with its theory of interpretation.

The thesis (xi) assumes that the understanding of some propositional attitudes, in part, involves normative judgments ${ }^{4}$ - especially when the propositions embedded in such attitudes are themselves normative. This point is raised en passant by Kevin Toh - who avoids discussing it, on the reason that it would not lead to relevant implications for the sources thesis. However, as we shall see, it does lead to an objection to the refutation of incorporationism:

\footnotetext{
Of course, some philosophers have argued that attributions of psychological states, and of contents more generally, involve deployment of normative judgments (see e.g. Kripke 1982; Brandom 1994). If they were right, then ascertainments of social facts themselves would inevitably require appeals to normative considerations. But I believe that I am entitled to set aside this line of thinking for the following reason. Whatever the nature of psychological attributions, once that task is done, there is a question as to whether some further appeals to normative considerations are necessary to determine whether a particular law exists in a community or whether a law has a particular content. According to the common conception of legal positivism, the answer is negative. It is this answer (or a particular version of that answer which I will isolate in the next section) with which I want to take issue. For this purpose, in the spirit of philosophical division of labor, I will bracket the line of thinking about the normative nature of psychological attributions (TOH, 2008, 451).
}

Our point here is precisely the prior task of attributing a state of mind to someone. As a rule, in interpreting a particular set of interrelated statements and propositional attitudes of someone else, we do so within a context, and we assume that they make sense, that they are coherent with each other, and that the concepts used are public (are, or at least can be, shared with us). This mental operation may 
occur automatically and intuitively, or be the outcome of reflexive deliberation; the enunciator may sometimes be asked to explain the meaning of the statement - but this results useless, either because it does not free us from interpreting the meaning of its explanation, or because (unless one assumes a 'strong version' of the the first-person authority thesis ${ }^{5}$ ) the enunciator himself may not understand better than the listener the meaning of his first assertion. Often, however, such a request may be physically impossible: it would not, e.g., be possible nor useful for judges nor citizens to consult a lawmaker to ensure they understood a law.

In short, if an authority's statements are normative and use the same language morality uses ${ }^{6}$; if she demands legitimate authority (or if she is treated as such); if the individual to whom they are directed shares the same concepts that they use; if the dependence thesis (or that of normal justification) is true (i.e., authoritative statements are supposed to be justified on dependent grounds), and so on... then it is plausible to use moral deliberation to understand the authority's intention - and so to understand the norm that should guide behavior. Thus, if moral deliberation gives someone access to the moral psychology of the authority, the subject will be justified in using it; and if her conclusion is correct (i.e., if it allows him to understand the intention of authority), one can say that she has gained knowledge of the meaning of the norm.

In reality, Raz admits this possibility when he states that it is possible for the subject to understand and follow a norm by establishing what is morally required:

It may be worth pointing out that the view does not require that every person should be able to identify the law without recourse to moral considerations. [...] Nor does it deny that it may be possible to identify the law using moral reasoning. Indeed, it follows from my doctrine of authority that if one knows that the legislature did enact the morally required law it should be possible to identify the law by establishing which law was morally required. However, the thesis that it is possible to identify the law without recourse to moral argument is not satisfied if to identify the law one has either to rely on moral considerations or to rely on the word of an expert who relies on moral considerations (RAZ, 2009, 4).

Given that it is possible to be aware of the identity and content of a legal norm by moral deliberation in that indirect way in some cases, there is no a priori reason to think that there is not, in some legal system, at least one rule whose identity and content can only be identified by such moral deliberation - i.e., a case in which one must ask whether some behavior is reasonable, or just, or cruel, or wicked... in order to have access to the intention of the authority, and so to the meaning of the norm. In doing so, the interpreter will be complying and following the authority; and it will be fallible, insofar as it is possible to err by doing such an operation ${ }^{7}$. Finally, if this is possible for a single norm in a single system, it follows that it is possible for several of them, in several systems - since we specified no other property of such a system.

This kind of 'indirect moral deliberation' is paradigmatic of systems of 'divine authority'. It is presupposed in discussions as distinct as the dialogue between Socrates and Euthyphro about the concept 
of impiety, or in the relationship between Revealed Law (divine positive law) and human law in Christian tradition; or even in discussions about the relationships between fiqh (Islamic law theory), ijtihad (the legal interpretation in Islamic courts), and Shari'a (Emon, 2009). Even the precept of the halakhah (the Jewish legal tradition) that the interpretation of the Torah dispenses with divine intervention (ba-shamayim hi, 'it is not in Heaven', in Deuteronomy 30:12) must be understood in the sense that it is the interpretation of His Will ${ }^{8}$.

Raz considers his conclusion that 'interpretation in accord with legislative intention is not demanded by any realistically conceivable theory of authority' does not apply to authority based on revelation (RAZ, 2009, 298). However, if this interpretive requirement stems from a requirement of the concept of authority, why should it exclude the idea of divine authority ${ }^{9}$ ? After all, nothing indicates that this concept (even if it is empty, or just fictitious) is necessarily different from authority in general; on the contrary, historically, philosophers have treated them in similar ways.

If the relevant distinction is that divine authority would be infallible or omniscient (thus having supernatural and privileged access to the meaning and application of its norms), it would be possible to maintain that, in this case, the Radical Intention Thesis (i.e., the divine commandment is completely identical to the divine intention) applies, whereas for human authorities the Authoritative Intention thesis is more adequate (RAZ, 2009, 265 e.). Still, epistemically, the interpreter would be in the same situation in both cases, to the extent that he would have only a limited knowledge ${ }^{10}$ of divine mental states - just like the way she discovers mental states of other human beings.

If this is correct, the imperative to 'honor father and mother' is (or at least can be) the same if written on tablets of stone from the heavens, or if uttered by priests, or if repeated by the very same parents (i.e., it has the same semantic content). And if, in the first case, it is an authoritative directive able to guide behavior (for, by dishonoring my parents, I not only fail to follow the reasons I would have to honor them - which might conflict with other primary reasons - but also fail to follow a divine prescription $^{11}$ ) and able to exclude primary reasons I would have for not performing the prescribed action (instead of a grant of discretion to decide, by myself, what counts as honor in each case), it may apply to the other cases as well. This means the imperative satisfies the preemptive thesis above.

This 'weaker' version of the preemptive thesis - i.e., the idea that it excludes only reasons conflicting with the norm - is consistent with other passages in Raz's work:

\footnotetext{
A binding authoritative directive is [...] an exclusionary reason, which is a reason for not following (i.e., not acting for) reasons that conflict with the rule. That is how authoritative directives pre-empt. [...] These exclusionary reasons do not, of course, exclude relying on reasons for behaving in the same way as the directives requires. [...] Hence the preemption excludes only reasons that conflict with the authority's directive (RAZ, 2009, 144).
}

So, it follows: 
xii. by (xi), to interpret the attitude that underlies the norm, it may be necessary to take into account the considerations that would make the norm justified;

xiii. by (xii), for a norm to guide behavior, it may be necessary to take into account considerations that would make it justified;

xiv. Contradiction: by (iii) to be authoritative, a norm must be capable of (a) guiding behavior and (b) of being identified without the subject being required to deliberate on the reasons that would justify the action determined by the norm. By (xiii), for a norm to guide behavior, it may be necessary to take into account considerations that would make it justified.

To avoid the conclusion in (xiv), it would suffice to let go the second sentence (b) from (iii); this would keep the rest of the theory of authority intact. In fact, the theory of authority itself would not lose anything without this 'proscription of moral deliberation' - except that, in this case, it would be impossible to conclude (vi): the refutation of the incorporation thesis.

\section{Conclusion: Why does the anti-incorporation argument fail?}

We can now synthesize Raz's argument: if (a) the law claims legitimate authority, then (b) it must be able to guide a subject's behavior and to be identified without recourse to moral deliberation. However, (c) moral concepts depend on moral deliberation for their application, and (d) norms that incorporate moral concepts require moral deliberation; so (e) by (b \& c), legal norms do not incorporate them. This justifies the adoption of the (supposedly) only viable alternative conception of law, the sources thesis, which can be read as: (f) the law is based exclusively on a set of facts (attitudes, beliefs or intentions - mental states or dispositions) relative to an authority.

There is no shortage of criticisms to this thesis, but the one we formulate here is: $(\mathrm{g})$ to be enforced, a norm must be understood, which implies knowing and interpreting the propositional attitude on which it is based - and, at least in some cases, (h) what would be the case if their authority were legitimate - i.e., the very understanding of that attitude may require normative judgments. So, (i) a legal norm may be known by moral deliberation; ( $j$ ) then, at least in some cases (as when direct information on authority's intention is lacking), moral deliberation is necessary to follow it - which contradicts (b).

The reader might be tempted to accuse us of injustice to Raz; after all, as mentioned above, he could 'bite the bullet' and reply that when interpretation depends on moral deliberation, even to discover the intention of authority, we are facing a legal gap - i.e., since there are no factual criteria based in which to decide whether the legal proposition is true or false, the interpreter has discretion (RAZ, 1979, 75). That said, there are four further considerations.

First, what we have attacked above was only the refutation of the incorporation thesis, based on the theory of authority; our reasoning is agnostic about the trichotomy: sources thesis, interpretivism 
and incorporationism. We are not, so far, making a full defense of the incorporation thesis. Second, it is necessary to avoid using one of these theories as a premise to conclude for the refutation of others, given the risk of begging the question. Therefore, one cannot argue for the sources thesis starting from the Raz's conception of legal gap, since this presupposes the very sources thesis; in the same way, we cannot base Dworkin's interpretivism on the theory of law as integrity by presupposing his theory of interpretation $^{12}$.

Third, one should avoid mixing the question 'what the law determines' with 'how the case should be decided, according to law' - a distinction often emphasized by Raz $(1995,328)$ himself. The former would correspond to the debate about the concept of Law, where we may consider the sources thesis; the latter refers to legal reasoning, and $\operatorname{Raz}(1995,340)$ makes explicit that it might require moral reasoning. Nevertheless, this distinction is undermined by Raz's anti-incorporation argument. For to arrive at the (ontological) conclusion that moral concepts cannot be incorporated into law, his argument presupposes that the concept of authoritative directive proscribes moral reasoning (which is a practical or even epistemic issue).

If jurisprudence is an ontological theory about the meaning and validity of legal norms (and propositions derived from these norms and their enforcement), without imposing epistemic or methodological constraints on how agents should draw inferences from these norms (and therefore, on how they interpret and apply them), then it does not entail any a priori restriction on using moral reasoning - and so cannot be used to justify the anti-incorporation argument above. We can imagine, for example, that moral concepts are capable of incorporating both empirical and mathematical quantifications, insofar as the enforcement of a legal norm depends on the correction of the incorporated proposition. In this case, the incorporation may seem rather contingent and trivial; after all, when law demands arithmetical reasoning or empirical research, we do not say that mathematics and science have been incorporated into law. However, we do say that 'X must pay a thousand dollars', or 'a testament with only two witnesses is invalid' or 'sea-life mass-killing is an environmental violation' are legal propositions. And if, in law enforcement, a party commits a factual error, we say that a right has been violated; it must be so, if we intend to apply law to reality (if there is such a thing as a factual basis of legal facts), particularly for a theory that emphasizes that 'law is a matter of fact.' Nevertheless, if the anti-incorporation argument were correct, it would prevent even this kind of trivial incorporation. For Raz $(1979,75)$, we should not say 'this contract is invalid, because it is unfair, and there is a norm that prohibits unfair contracts', but 'this contract is invalid because a judge has so ruled, authorized by a law which proscribes unfair contracts.'

Finally, even if at the theoretical level we denied (in our counterexamples above) that moral norms can be incorporated into law, we should now highlight that such denial would not be accessible to the legal interpreter. Just as the authority cannot claim she is illegitimate, nor that her commands are not justified by dependent reasons (by virtue of the claim thesis and the dependence thesis ${ }^{13}$ ), the interpreter, in our counterexample above, could not claim to be creating new law - at least not while 
doing $\mathrm{it}^{14}$ (except for cynicism, of course). After all, if interpreters recognized that the norm was indeterminate, and not just uncertain, and that moral inquiry led them to create law, rather than to discover it, they could not present their decisions as binding because of the original authority. Therefore, the anti-incorporation thesis would incur in a condemnation similar to what Bernard Williams (2005, 165 ) assigned to utilitarianism: if true, it is better that people should not believe it; if false, it is certainly better not to believe it. 


\title{
Notes:
}

${ }^{1}$ Doutor em Filosofia (UFRGS, 2018), Mestre em Filosofia (UFRGS, 2015), Especialistas em Direito Público (IMED, 2010), Bacharel em Direito (UFRGS, 2009). Analista do Banco Central. E-mail: ramiro.peres@ufrgs.br

\begin{abstract}
${ }^{2}$ One of the main objections to Raz is that a legal system could be devised without the presence of any of the facts corresponding to that claim (DWORKIN, 2006, 231-2; HIMMA, 2001b, 289-90). Similarly, it may be argued that the claim thesis has an epistemic implication: if it were a conceptual truth of legal systems, then it would be impossible to know that there is a legal system without knowing whether there is a corresponding claim - although this is precisely the case of a legal system of which little is known, such as that of North Korea (HIMMA, 2002).We will not analyze such criticisms here; if they are correct, it is possible to divide the class of legal systems between those to which the thesis of the claim does not apply and those to which it applies - and the following argument aims the latter.
\end{abstract}

3 This relationship between the claim to legitimacy and law's capacity to exercise de facto authority has some empirical basis, since there is reason to believe that the success of this preemptive function of law depends on its subjects taking its authority as legitimate (PRIEL, 2010).

It may seem arbitrary that, for the claim to be possible, features that make true the claim of authority should be present, but not those that make true the claim to legitimacy. According to Raz, "If it [a legal system] lacks the moral attributes required to endow it with legitimate authority then it has none. But it must possess all the other features of authority, or else it would be odd to say that it claims authority." (RAZ, 1995, 215) The objection is circumvented by reformulating (ii): 'the law claims that its authority is legitimate' - which is to say simply that, for something to be an authority, it must claim legitimacy.

${ }^{4}$ The plausibility of this thesis is reinforced by the sensitivity of intention assignments to normative assessments in folk psychology: people are more likely to attribute intentionality to negative side effects than to positive ones (KNOBE, 2003).

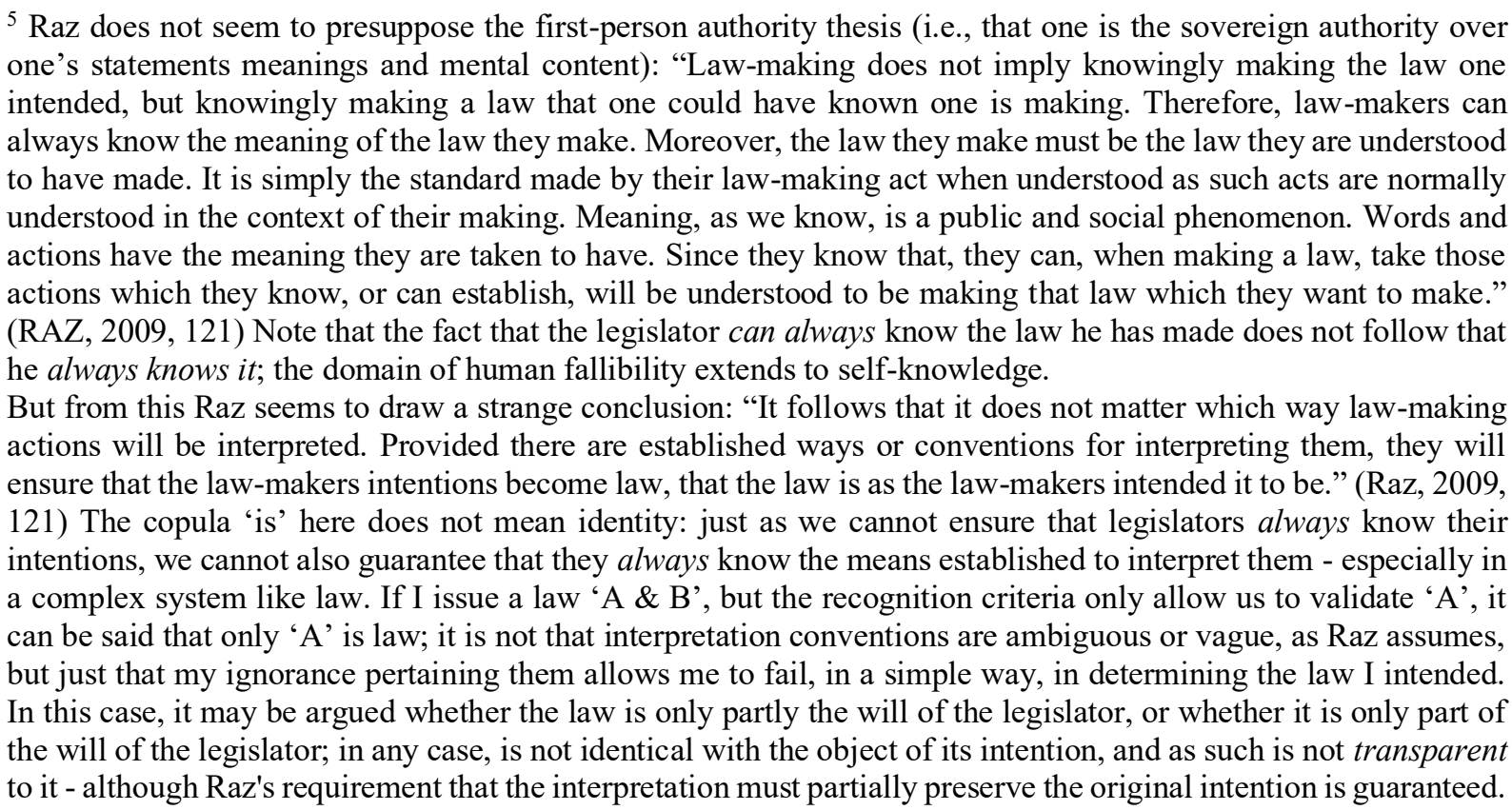

${ }^{6}$ However, they are often pronounced from a detached point of view (RAZ, 1979, 156; 2002, 177).

${ }^{7}$ If, by committing this mistake, an interpreter creates new law, it is another matter. The point is that by correctly interpreting the authoritative directive, it does not create a new one. One of the noteworthy points of Raz's theory of interpretation is that even when it is impossible to discriminate between conservative and creative interpretations, this does not mean that the conceptual distinction does not exist (see RAZ, 2009, 116-20).

${ }^{8}$ This is one of the usual interpretations of the Talmudic parable of the oven of Akhnai, where a group of rabbis argues with God Himself about the impurity of an oven (see LUBAN, 2004). 
${ }^{9}$ I am not suggesting that every occurrence of the word 'authority' refers the very same concept. In this case, however, theorists of divine authority usually treat it as something related to secular authority; even if one of those were a fiction, it would not follow that the very concept would be inconsistent. Gardner (2012), an atheist and one of Raz's greatest advocates, uses the notion of divine authority to draw similarities between Kelsen's Basic Rule and the Rule of Recognition - besides criticizing Dworkin.

${ }^{10}$ Propositional knowledge. In speaking of the interpreter, I am excluding the figure of the 'prophet', whose knowledge of revelation would be privileged, derived from divine inspiration. Note that I am not assuming that the interpreter is correct in its basic premise - i.e., that God exists and has issued a command.

11 Similarly, Dworkin $(2006,207)$ imagines a trader who, having worked a lifetime by the principle of caveat emptor, was converted to a religion that preached good faith in all trade transactions; this trader would be justified in believing to have violated a religious prescription.

12 Dworkin $(2011,403)$ argues that the debate over the concept of law is hopelessly circular - but that his theory would be superior because in interpretivism, there might be a virtuous circle: "We construct a conception of lawan account of the grounds needed to support a claim of right enforceable on demand in that way - by finding a justification of those practices in a larger integrated network of political value. We construct a theory of law, that is, in the same way that we construct a theory of other political values - of equality, liberty, and democracy." (DWORKIN, 2011, 405)

13 The claim to legitimacy, at this point, has an effect similar to that of Robert Alexy's 'claim to correctness' (see GARDNER, 2012, 125).

${ }^{14}$ Obviously, we are not referring to cases where law expressly grants discretion to judges. 


\section{References}

DWORKIN, Ronald. "The Model of Rules." The University of Chicago Law Review 35, n. 1 (1967), p. 14-46. doi: 10.2307/1598947.

DWORKIN, Ronald. O Império do Direito. Trad. Jefferson Luis Camargo. São Paulo: Martins Fontes, 1999.

DWORKIN, Ronald. Levando os direitos a sério. Trad. Nelson Boeira. São Paulo: Martins fontes, 2002.

DWORKIN, Ronald. Justice in Robes. Cambridge, Massachussets: Belknap Harvard University Press, 2006.

EMON, Anver M. "To Most Likely Know the Law: Objectivity, Authority, and Interpretation in Islamic Law" (September 17, 2009). Hebraic Political Studies 4, n. 4 (2009), p. 415-40. Retrieved from: https://ssrn.com/abstract=1474746.

GARDNER, John. Law as a leap of Faith. Oxford: Oxford University Press, 2012.

GREENBERG, Mark M. "How Facts Make Law." Legal Theory 10, no. 03 (2004). doi: $10.1017 / \mathrm{s} 1352325204040212$.

HART, Herbert Lionel A. The Concept of Law. $2^{\mathrm{a}}$ Ed. New York: Oxford University Press, 1994.

HIMMA, Kenneth Einar. "The Instantiation Thesis and Raz's Critique of Inclusive Positivism." Law and Philosophy 20, n. 1 (2001a), p. 61-79. Retrieved from: https://ssrn.com/abstract $=316869$.

HIMMA, Kenneth Einar, "Law's Claim to Legitimate Authority." In COLEMAN, Jules L. (ed.). Hart's Postscript: Essays On The Postscript to the Concept of Law, Oxford: Oxford University Press, 2001b. Retrieved from: https://ssrn.com/abstract=928095.

HIMMA, Kenneth Einar, "Inclusive Legal Positivism." COLEMAN, Jules L. \& SHAPIRO, Scott (eds). Oxford Handbook of Jurisprudence and Legal Philosophy. Oxford: Oxford University Press, 2002. Retrieved from: https://ssrn.com/abstract=928098.

HIMMA, Kenneth Einar, "Revisiting Raz: Inclusive Legal Positivism and Our Concept of Authority." American Philosophical Association Newsletter on Philosophy and Law 6, n. 2 (2007), p. 1-19. doi: 10.2139/ssrn.953392.

LUBAN, David."The Coiled Serpent of Argument: Reason, Authority, and Law in a Talmudic Tale. Epilogue: Law and Fable." Chicago-Kent Law Review 79, n. 3 (2004), p. 1253-1288. Retrieved from: https://scholarship.kentlaw.iit.edu/cklawreview/vol79/iss3/33.

MEDEIROS, Bernardo Abreu. Positivismo Jurídico Inclusivo: a possibilidade de incorporação de valores morais ao direito nos estados constitucionais contemporâneos. 110f.. Dissertação (Mestrado em Teoria do Estado e Direito Constitucional) - Faculdade de Direito, Pontifícia Universidade Católica do Rio de Janeiro, 2009. 
PRIEL, Dan. "Jurisprudence and Psychology." New Waves in Philosophy of Law, (forthcoming). Osgoode CLPE Research Paper 49, November 26, 2010. Retrieved from: https://ssrn.com/abstract=1715647.

RAZ, Joseph. The Authority of Law: essays on law and morality. New York: Oxford University Press, 1979.

RAZ, Joseph. Ethics in the public domain: essays in the Morality of Law and Politics. Oxford: Clarendon Press, 1995.

RAZ, Joseph. Practical Reason and Norms. $3^{\text {a }}$ Ed. New York: Oxford University Press, 2002.

RAZ, Joseph. Between Authority and Interpretation: on the Theory of Law and Practical Reason. New York: Oxford University Press, 2009.

SHAPIRO, Scott J.. “Authority." Stanford/Yale Jr. Faculty Forum Research Paper 00-05; Cardozo Law School, Public Law Research Paper No. 24, 2000. doi: 10.2139/ssrn.233830

TOH, Kevin. "An Argument Against The Social Fact Thesis (and some additional preliminary steps towards a new conception of legal positivism)", Law and Philosophy 27, n. 5 (2008), p. 445-504. Retrieved from: https://ssrn.com/abstract=1650749.

WILLIAMS, Bernard. Moral: uma introdução à ética. Trad. Remmo Manarino Filho. São Paulo: Martins Fontes, 2005. 